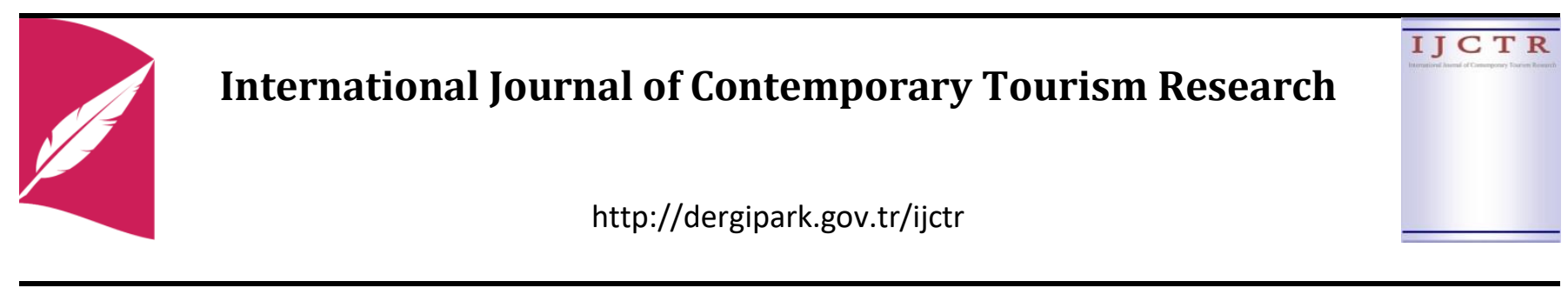

\title{
EXPLORING RESIDENTS' PERCEPTION ON GASTRONOMIC TOURISM DEVELOPMENT: A STUDY OF INTERNATIONAL URLA ARTICHOKE FESTIVAL
}

\section{Research Article}

Feray İRİGÜLER ${ }^{1}$

\begin{abstract}
Commodification of local food through food festivals is not only a pleasurable attraction for tourists but also a great advantage for local residents and the well-being of the community. Bearing this in mind, the study aims to explore residents' perceptions of food festivals based on the specific case of 5th International Urla Artichoke Festival. A qualitative approach was adopted to highlight residents' views on festival experience. The results indicated that the event is perceived as an opportunity for the development of gastronomic tourism in the region through promotion of the product and the place, while boosting agricultural productivity and building social capital.
\end{abstract}

Keywords: Festival, Festival Tourism, Gastronomic Products, Food Tourism, Local Food

JEL Classification Codes: Z32, L83, Q01

\footnotetext{
${ }^{1}$ Lecturer, İzmir University of Economics, School of Applied Management Sciences, Gastronomy and Culinary Arts Program, feray.iriguler@ieu.edu.tr, orcid.org/0000-0003-1313-1600
}

“İrigüler, F. (2021). Exploring Residents' Perception on Gastronomic Tourism Development: A Study of International Urla Artichoke Festival, International Journal of Contemporary Tourism Research, Vol 5: No: 1, p.77-86, doi: 10.30625/ijctr.834689” 


\section{INTRODUCTION}

Festivals are emerging worldwide as a growing and dynamic segment of the tourism and leisure industries, which yield significant economic, socio-cultural, and political impacts on the destination area and host groups (Viviers and Slabbert, 2012; Jago and Dwyer, 2006; Mossberg 2000). Festivals connect and empower individuals across diverse communities. Increasingly, festivals and events are found to enlarge social capital, and in consequence, social sustainability (Arcodia and Whitford, 2008). Food, on the other hand, represents a kind of cultural power and a sense of identity for human societies, in which biological need for nutrition and the social act of eating gain a particular meaning (Simpson, 1999). Food is a way of communication, and represents the culture of those who consume it (McAndrews, 1999). Food is the principal element of cultural values, and territorial identity. Growing interest in food and food-related tourism activities has made it a popular theme and central focus of festivals.

Figure 1. Emergence of food festivals

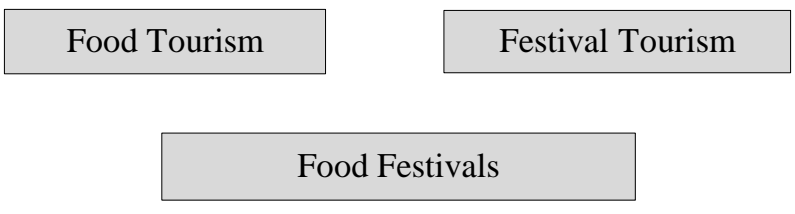

Source: Simpson, 1999; Viviers and Slabbert, 2012.

Food is regarded as a major theme in festival celebrations. Tourists can experience new cultures and new flavors thorough experiential participation and forming social relationships at the same time in a festive environment. This interaction between host communities and tourists generates a deep appreciation of culture reciprocally. However, the success of any festival depends on the intense involvement of local residents from the planning stage to the execution and evaluation of the event (Kalkstein-Silkes et al., 2008).

A number of studies have inspected food festivals, but there is very little research on its impact on local residents and host communities. Since the existing literature on residents' experiences and perceptions of food festivals is very scarce, the present study helps to fill this gap in the literature by examining host community members'perspectives on a local food festival. The article addresses the role of food festivals on gastronomic tourism development and the promotion of the destination along with other social and economic benefits, based on residents' perceptions.

\section{LITERATURE REVIEW}

\section{Festival Tourism}

Festivals are 'specific rituals, presentations, performances or celebrations that are consciously planned and created to mark a special occasion or to achieve particular social, cultural or corporate goals and objectives' (McDonnell et al., 1999). Festivals are increasingly significant for tourism regions and the tourism industry, particularly in rural areas with more limited sources of income than metropolitan areas (Jackson et al., 2005). It has been acknowledged that festivals are critical from more multiple perspectives as they have not only economic, but also social and cultural importance for the host localities and regions (McDonnell et al., 1999; Dimmock and Tyce, 2001; Jago and Dwyer, 2006; Mossberg 2000).

Recent proliferation of festivals has a number of causes, but mainly relates to a response from communities desiring to reassert their identities in the face of cultural dislocation brought by rapid structural change, social mobility and globalisation processes (Kim et al., 2014; Blichfeldt and Halkier, 2014; Lee and Arcodia, 2011). Some festivals are grounded on long-established history that has been either rediscovered, reinvigorated or reinvented rituals, while others have been created, usually as a result of myriad of social, political, demographic 
and economic realities. Other places become noted purely as a redult of the festivals they host, as in the case of Woodstock Music and Art Festival of USA; in other situations, festivals might be a supportive offer of a destination for differentiation purposes. No matter what the nature of festivals is, it allows people to reflect images of themselves and their lifestyles to audiences which is a cumulative set of identities and collective conscious; hereby, traditions can be maintaied and passed on to future generations, and history can be retold. Besides, festivals constitute an occasion for all hosts, including old ones, newly arrived and expatriates to generate collective experiences, revive memories and feelings of belonging linked to the place (Picard and Robinson, 2006).

Table 1. Impacts of Festivals

\begin{tabular}{|c|c|c|}
\hline \multicolumn{3}{|c|}{ Impacts of Festivals } \\
\hline & $\begin{array}{c}\text { Positive impacts } \\
\end{array}$ & Negative Impacts \\
\hline Economic & $\begin{array}{l}\text { boost the economy in local regions } \\
\text { increased revenues and employment }\end{array}$ & $\begin{array}{l}\text { inflated prices } \\
\text { residents' exoduses } \\
\text { interruption of normal prices }\end{array}$ \\
\hline Physical & $\begin{array}{c}\text { enhanced quality of life } \\
\text { urban renewal } \\
\text { increased infrastructure } \\
\text { increased public awareness }\end{array}$ & $\begin{array}{c}\text { environmental damage } \\
\text { noise } \\
\text { overcrowding } \\
\text { Traffic congestion } \\
\end{array}$ \\
\hline Political & enhancement of image & reflection of political ideology \\
\hline Socio-cultural & $\begin{array}{l}\text { social cohesiveness } \\
\text { build pride among local citizens } \\
\text { community collaboration } \\
\text { increased communication } \\
\text { development of communal ties }\end{array}$ & $\begin{array}{c}\text { disruption of resident lifestyle } \\
\text { increased criminal activity } \\
\text { socia dislocation } \\
\text { vandalism }\end{array}$ \\
\hline
\end{tabular}

Source: Yolal et al., 2016; Y1ldı and Polat, 2016; Jago and Dwyer 2006; Jackson et al., 2005.

The community is an important role player in events, due to its active involvement in planning and managing events, and also its role as hosts to tourists. Their opinion regarding the impact of events is therefore important and needs to be researched because it can influence the sustainability of an event or festival (Viviers and Slabbert, 2012).

\section{Food Tourism}

Food tourism is "the desire to experience a particular type of food or the produce of a specific region" (Hall and Sharples, 2003). Tourists believe that experiencing a region or country's food is essential to understanding its culture (Boyne \& Hall, 2003). Since food and beverages are tied to a region's heritage, history and culture, culinary tourism extends beyond trying new and exotic foods. It unites anthropology, folklore, and history, and can comprise ethnic recipes, international cookbooks, folk and food festivals, cooking shows, cooking schools, specialty food stores, food tours, breweries, wineries, and historical attractions (Slocum and Curtis, 2018). Food tourism emphasizes cultural distinctiveness, a quality experience, or a product unique to a specific region. These experiences can be exotic, like eating ostrich at the Carnivore Restaurant in Nairobi, Kenya, or many involve an event centered on a regional specialty, such as garlic ice cream at the Garlic Festival in Gilroy, California, USA. Managing authenticity and commodification is an important part of developing food tourism because the long-term sustainability of any tourism product or destination depends on economic success. At the same time, it is vital to ensure that locals feel that the tourism product is authentic where tourism is a means to preserving cultural traditions and develop community pride (Barroco et al., 2018). Figure 2 shows some of the remarkable advantages of developing food tourism: 
Figure 2. Advantages of Food Tourism

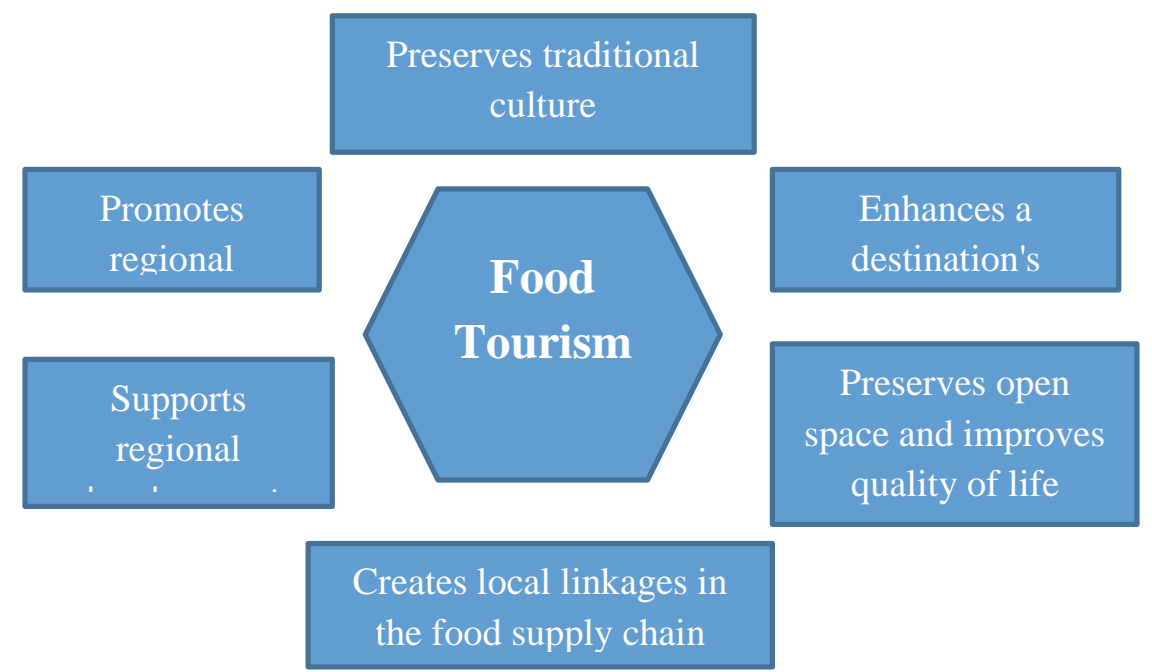

Source: Slocum and Curtis, 2018.

Promoting local foods and local food traditions allows communities to develop pride in their heritage and culture, which can lead to the development of social capital, the links, shared values and understandings that enable mutual trust and cooperation among individuals and groups. Food tourism has the potential to provide positive influences for sustainable development by decreasing negative environmental impacts, and developing social capital (Keeley, 2007). Incorporating authentic food into the tourism experience can be a powerful means for sustaining and reinforcing a destination's cultural identity and cultural capital.

\section{Food Festivals}

Food festivals are a collective celebration of an authentic product, and are hallmark events that are held on a one-off or regular basis either internationally, nationally or regionally. They are a tool for rural communities to promote local commodities, adding value to already existing products. Regions known for specific food and drink products provide an opportunity for the local community to promote products that they perceive as valuable and unique to themselves and / or characteristic of the area (Çela et al., 2007). Food tourism and events are often described as tools for sustainability of traditional farming in peripheral areas within national and international food and agricultural policy contexts (de Jong and Varley, 2018). Increased demand for food festivals has been found to animate the emergence of educational visitor attractions, inspire the retention and development of culinary and agricultural skills, and offer vital support to dynamic traditional industries and small businesses (Everett and Aitchison, 2008). Food is recognized as an expression of heritage based on historical landscapes, traditional farming heritage and social celebrations; local recipes promoted through tourism reflect traditional herbs and spices, and traditional cooking techniques (Slocum and Curtis, 2018).

Today's food festivals are derived from the practices involved in medieval feasts (Rusher, 2004), and the essence today remains the affirmation and celebration of common cultural values. Such events raise awareness of the host community and region, repositioning or reaffirming the region in the minds of festival attendees. Festivals provide a community with a means expressing its values and regional identity to a wider audience, and also serve as a tool to transfer cultural values to future generations.

The aim of this study is to evaluate the impact, importance and attributes of food festivals using the example of International Urla Artichoke Festival, based on the perceptions of local residents.

\section{International Urla Artichoke Festival}

Urla is a coastal town with a population of 66.360, located 35 kilometers west of İzmir City, as shown on the map below. Urla is known for its fishery, 
floriculture, fresh herb varieties, artichokes, olive, olive oil and wine production. The city's foundation dates back to long before the Hellenistic Civilization, as evidenced by archaeological findings, and this area was known as Klazomenai on the coast, and Vourla in the interior parts in ancient times. Following the invasion of Dor and Aka immigrants, the city which was founded by the Ions, come under the domination of Persians, Greeks, Romans, Byzantines, Seljuks and Ottomans respectively.

Figure 3. Map of Urla, İzmir, Turkey

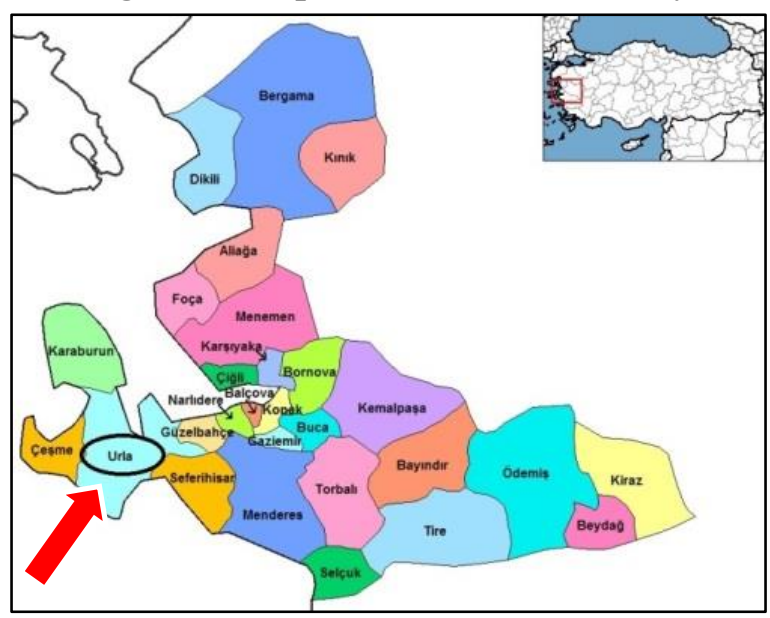

International Urla Artichoke Festival take place at the end of April, and is organized by Municipality of Urla and Municipality of İzmir, Izmir University of Economics and Délice Network of Good Food Cities. The event has been increasingly successful with growing attendance over several years. It is a three-day annual event organized for the fourth time in 2018, and was awarded as the festival of the year by Shining Star Awards in 2016. The success can be seen in the following statistics (Bakırc1 et al., 2017): Artichoke planting has increased by 43 percent and 1300 acres of additional artichoke production was initiated in the region due to the festival. The number of visitors increased from 60 thousand in 2016 to 600.000 in 2018, based on highway entrances. Accommodation rates in hotels were $80 \%$ above average. Producers sold more than two million artichokes in three days. In addition to the artisan products exhibited at 1200 stalls, 200 additional stalls were exclusively reserved for artichoke sales. Besides these specialty vendors, the festival program was enriched with culinary demonstrations from award-winning foreign and local chefs, souvenir vending stands, seminars, open-air talk shows, demonstrations by celebrity chefs, competitions, special guest contacts, activities for children, musical shows, and arts \& crafts workshops at different locations of Urla, and it ended with a fund-raising event which was a long table lunch event in an artichoke field, in aide of orphans in need of protection.

\section{METHODOLOGY}

Due to the nature of the study and potential informants, a qualitative approach was adopted, and face to face interviews were conducted with 12 participants. Resident respondents were selected by using purposive sampling method in order to obtain a diversified sample. Only habitants, local event organizers and local product vendors were included in the interview session. Each interviewee was assigned a numerical code (I1, I2,...I12). Semi structured questions were then developed to obtain valuable information and findings regards to research interests. Malgaca Pazarl, Cumhuriyet Meydanı, Sanat Sokağ and Demircili Sokak were chosen as the venue for data collection as these squares and streets served as main event spaces. The interviews were conducted in the month of April 2019 during the festival and were limited to ten to fifteen minutes, due to the intense pedestrian traffic and time constraint of interviewees. The final sample size was determined as the data saturation had been reached, and no new information emerged. The interviews were audotaped and transcribed verbatim. Statements with related concepts were grouped according to core themes based on the principles of grounded theory.

\section{RESULTS AND DISCUSSION}

Food festival as a tool to promote local product: As the main focus of festival was based on artichokes, and related activities, it was widely promoted at regional, national and international level, resulting in increased local food awareness among residents of Urla. In 2017, the Urla artichoke was geographically indicated by Turkish Patent and Trademark Authority, upon the initiatives of Izmir Commodity Exchange. The relevant comments of interviewees are listed in table below: 
Table 2. Interviewee Remarks on Promotion of Local Product

\begin{tabular}{|c|c|}
\hline Interviewees & Remarks \\
\hline $\begin{array}{l}\text { I-12 } \\
\text { Male, } 56, \\
\text { Greengrocer }\end{array}$ & $\begin{array}{l}\text { I'm a } 56 \text { years old man who was born and raised in Urla but I'd never witnessed so } \\
\text { many people talking about artichoke and a festival of this scope in my town before } \\
\text { this festival. Artichoke was always on our family diet just as any other vegetable but it } \\
\text { has become number one in our hearts. I talk about it and various dishes prepared } \\
\text { with Urla artichoke wherever I go. }\end{array}$ \\
\hline $\begin{array}{l}\text { I-2 } \\
\text { Female, } 42 \\
\text { Audience }\end{array}$ & $\begin{array}{l}\text { As a resident of Urla, I haven't counted the number of photos, videos and the like that } \\
\text { I shared on my social media accounts during the festivals in the past } 4 \text { years. All } \\
\text { artichoke related stuff...all my friends and relatives living in neighboring cities came } \\
\text { to visit us during the event. I feel like there is no other place than Urla where } \\
\text { artichoke is produced. That's how deeply we took ownership of this vegetable. }\end{array}$ \\
\hline $\begin{array}{l}\text { I-8 } \\
\text { Female, } 50 \\
\text { Housewife }\end{array}$ & $\begin{array}{l}\text { I've been a stall-holder on the main festival ground in the past } 2 \text { years and I am } \\
\text { selling stuffed artichokes, artichoke rolls and artichoke pilaff. People queue to buy } \\
\text { them. They get so much attention from the visitors that we work day and night in the } \\
\text { kitchen with my friends to have enough of them for the next day. }\end{array}$ \\
\hline
\end{tabular}

Food festival as a tool to promote 'the place': and thus build pride among local citizens and Festivals are often explicitly connected to the reinforce the identity of cities (Jarman, 2018). destinations in which they take place, and such Some of the related remarks of interviewees are activities brings attachment to place. Festivals listed in table below: create, shape, or reinforce the ideology of a place,

Table 3. Interviewee Remarks on Promotion of Place

\begin{tabular}{|l|l|}
\hline Interviewees & Remarks \\
\hline I-1 Male, 68 & $\begin{array}{l}\text { This festival made me proud to be an Urla resident. I didn't believe that the name of } \\
\text { Retired }\end{array}$ \\
$\begin{array}{l}\text { Urla would be associated with artichoke by everyone before the festival, but today I } \\
\text { seople asking me whether the festival will be held again this year or not. }\end{array}$ \\
\hline $\begin{array}{l}\text { I-10 } \\
\text { Student }\end{array}$ & $\begin{array}{l}\text { I'm from Urla and study arts in Izmir. I see festival posters on billboards all around } \\
\text { the city months before the event. Izmir has several counties but Urla differentiated } \\
\text { itself by far with this festival and more people feel sympathy to my town. I'm very } \\
\text { pleased to see their attention. }\end{array}$ \\
\hline
\end{tabular}

Food festival as a tool to boost agricultural interconnections between traditional regional productivity: Agriculture and tourism represent industries such as agriculture, and emerging two of the world's largest industries. Food tourism industries, especially gastronomic tourism (Slocum can support regional economic growth; food and Curtis, 2018). Some of the related remarks of festivals in particular enhance and support interviewees are listed in table below:

Table 4. Interviewee Remarks on Food Festival and Agriculture

\begin{tabular}{|c|c|}
\hline Interviewees & Remarks \\
\hline $\begin{array}{l}\text { I-6 } \\
\text { Male, } 47 \\
\text { Farmer }\end{array}$ & $\begin{array}{l}\text { Every year we sell more and more artichoke. Artichoke production in Urla makes up } \\
\text { more than } 20 \% \text { of the total production in Turkey. This ratio has increased gradually } \\
\text { thanks to the festival and local authorities' initiatives. Now that it has a geographic } \\
\text { indication, I hope we will even produce more. }\end{array}$ \\
\hline $\begin{array}{l}\text { I-11 } \\
\text { Male, } 38 \\
\text { Restaurateur }\end{array}$ & $\begin{array}{l}\text { We've had approximately } 20 \text { times more customers during the festival than any other } \\
\text { day. And they all prefer artichoke dishes. While this is a great opportuniy for us to } \\
\text { promote our local dishes and an occasion to make economic benefits, I feel very } \\
\text { happy for the producers as well. The time of the festival is when the last artichoke } \\
\text { harvest is done; so the farmer is not left with unwanted artichokes. }\end{array}$ \\
\hline
\end{tabular}

Food festival as a tool to develop gastronomic tourism: Food is an important opportunity for interpreting the culture or the community. Thus, food can be used as an interpretive tool to deeply internalize a place's customs, heritage, celebrations, daily way of life etc. Gastronomic 
tourism is an experiential journey where food is viewed as a medium of experiencing the local socio-cultural structure of a region through its cuisine. Food festivals attract the attention of gastronomy travellers primarily for food, but also for the festive atmosphere they provide. Some of the related remarks of interviewees are listed in table below:

\section{Table 5. Interviewee Remarks on Food Festival and Gastronomic Tourism}

\begin{tabular}{|c|c|}
\hline Interviewees & Remarks \\
\hline $\begin{array}{l}\text { I-4 } \\
\text { Female, } 28 \\
\text { Server }\end{array}$ & $\begin{array}{l}\text { I've met a bunch of chefs, bloggers and celebrities while serving them. It's good to } \\
\text { see food experts in town because Urla wants to become a popular destination with its } \\
\text { gastronomy. When outsiders visit the festival, they also hear about the 'Urla Wine } \\
\text { Route', 'Klazomenai Olive Oil Production Facility' of the 6th century, beaches } \\
\text { around the town, and all the other things to do too... }\end{array}$ \\
\hline $\begin{array}{l}\text { I-9 } \\
\text { Male, } 30 \\
\text { Cafe owner }\end{array}$ & $\begin{array}{l}\text { While touring the stalls, I've seen so many different things that were prepared with } \\
\text { artichoke; dishes that we are not usually used to see, or traditional dishes adapted to } \\
\text { artichoke.. so the event also brought innovative recipes and these new recipes } \\
\text { awakened the curiosity of visitors, who become interested in revisiting our town. }\end{array}$ \\
\hline $\begin{array}{l}\text { I-7 } \\
\text { Female, } 45 \\
\text { Souvenir } \\
\text { shopkeeper }\end{array}$ & $\begin{array}{l}\text { I've seen many tour buses in town. Some were daily visitors as I learned from my } \\
\text { customers, but there were also tourists from other cities who did stay in and around } \\
\text { Urla. Our sales went considerably higher, which I'm very happy about! Streets are } \\
\text { full, hotels are full, restaurants are full...This is amazing for Urla. }\end{array}$ \\
\hline
\end{tabular}

Food festival as a tool to develop social capital: Festival attendance facilitates the augmentation of social capital, that is the processes between people which allow the establishment of a sense of cooperation, goodwill, reciprocity, belonging, and fellowship. A host community may derive numerous benefits from participating in or staging festivals. Festival attendance builds social capital by developing community resources. The organizers responsible for the administrative aspects must interact with local business and the general community for festival organisation
(Arcodia and Whitford, 2008). This interaction has several benefits: it raises awareness of community resources and expertise, forges social links between previously unrelated groups and individuals, identifies areas of potential development for community resources, and generally enhances stronger social connectivity between existing community organizations (Cooke and Wills, 1999; Mykletun, 2009; Wilks and Quinn, 2016). Some of the related remarks of interviewees are listed in table below:

Table 6. Interviewee Remarks on Building Social Capital

\begin{tabular}{|c|c|}
\hline Interviewees & Remarks \\
\hline $\begin{array}{l}\text { I-3 } \\
\text { Male, } 39 \\
\text { Retired }\end{array}$ & $\begin{array}{l}\text { No matter what our political views or ideologies or lifestyles are, we all worked in } \\
\text { close collaboration on this. And I think we did it. Municipalities handled the } \\
\text { organization and marketing part, producers provided the artichokes, women cooked } \\
\text { stuff to be sold on the stalls.Everybody shared one ambition; a successful festival.. }\end{array}$ \\
\hline $\begin{array}{l}\text { I-9 } \\
\text { Female, } 31 \\
\text { Public officer }\end{array}$ & $\begin{array}{l}\text { I've worked for the municipality for } 5 \text { years and actively take part in the organization } \\
\text { of the festival. This is something one person or one institution cannot do on its } \\
\text { own... We set up meetings every month and these meetings start up almost one year } \\
\text { prior to the event. We have a big team composed of municipality officers, scholars, } \\
\text { press and media representatives, civil society organization members, farmer and } \\
\text { agricultural producers coordinator, charity foundation representative...We try to } \\
\text { create a good synergy and make the most out of it. }\end{array}$ \\
\hline
\end{tabular}

\section{CONCLUSION}

Most research on festivals conducted to date discussed food festivals from the attendees' point of view, including visitors' profiles, market segmentation, motivations, behavioral intentions, and value perceptions (Li et al., 2018; Duran and Hamarat, 2014; Lee ate al., 2007; Yuan et al., 2005; Thrane, 2002). In contrast, this study aimed to analyze festivals from residents' point of view, 
and analyze how locals appraised the impacts of such events. In this sense, it was seen that the artichoke festival was evaluated positively by the majority of residents, who considered it as an opportunity to increase the number of visitors to their town. The interviewees confirmed, with varying emphasis, that incorporating local product to a festive event brought synergy to Urla, promoting local products and the region in general. They stated that incorporating a local product to a food festival strenghtened the attractiveness of Urla as a gastronomic destination. They also pointed out that the festival provided a platform to promote the local gastronomy products and served as a tool to develop gastronomic tourism. Considering the increase in artichoke production, the festival was perceived as a sustainable contribution to the economy and regional development. The interviewees highlighted that the festival reinforced the relationship among diverse stakeholders such as governmental and nongovernmental bodies, farmers, restaurateurs, residents, scholars and a range of other stakeholders, contributing to their social capital. It was also considered as an opportunity to build community pride, and an instrument that brought a strong emotional attachment to their place of residence.

Festivals are greatly intensing interest in local products. The steady increase in the number of food festivals, in parallel to the development of gastronomy tourism have yielded remarkable economic and social benefits, in particular with locals' support and adoption of the event. In this regard, International Urla Artichoke Festival was no exception; residents, organizers and all related stakeholders' perceptions of the event were affirmative. Yet, the festival's sustainability in the upcoming years should be monitored, with focus on the established variables in order to evaluate the direction of development, as well as its meaning for the residents.

Comprehension of festival experiences from residents' perspective can help event planners, local authorities and voluntary groups to better understand locals' desires and expectations, which will ensure the priority of local development in the organization of such events. It will also contribute to the success of the festival, as it provides meaningful insights from varying perspectives.
While this study provides an understanding of how food related festivals influence locals' perceptions of gastronomic tourism development, the findings are dependent on data from one single event, and therefore are not generalizable to all food festivals; thus, its replication of other food festivals in different locations would increase the validity of these results. Perceptions can be researched on a broader scale by including supporting institutions, organizations and official bodies in future studies. Future studies could also make comparative analysis of similar events to account for regional biases.

\section{REFERENCES}

Arcodia, C., Whitford, M. (2006). Festival attendance and the development of social capital, Journal of Convention \& Event Tourism, 8:2, 1-18.

Bakırcı, G. T., Bucak, T., \& Turhan, K. N. (2017). Bölge gastronomi turizmi üzerine yöresel ürün festivallerinin etkisi: Urla örneği. Journal of Gastronomy and Tourism Studies (5): 230-240.

Blichfeldt, B. S., \& Halkier, H. (2014). Mussels, tourism and community development: a case study of place branding through food festivals in rural North Jutland, Denmark. European Planning Studies, 22(8), 1587-1603.

Boyne, S., \& Hall, D. (2003). Managing food and tourism development: Issues for planning and opportunities to add value. In C.M. Hall, L. Sharples, R. Mitchell, B. Cambourne, \& N. Macionis (Eds.), Food tourism around the world: Development, management and markets (pp. 285295). Oxford: Butterworth-Heinemann.

Barroco, C., Augusto, L., \& Martins, L. (2018). Building food experiences: The case of food events in small regions. Food and Agricultural Tourism: Theory and Best Practice, 57-59.

Cooke, P., Wills, D. (1999). Small firms, social capital and the enhancement of business performance through innovation programmes. Small Business Economics, 13(3), 219-234.

Çela, A., Knowles-Lankford, J., Lankford, S. (2007). Local food festivals in Northeast Iowa communities: A visitor and economic impact study, Managing Leisure, 12: 2-3, 171-186.

De Jong, A., \& Varley, P. (2018). Food tourism and events as tools for social sustainability?. Journal of Place Management and Development. 
Dimmock K, Tiyce M 2001. Festivals and events: Celebrating special interest tourism. In: N Douglas, $\mathrm{N}$ Douglas, R Derret (Eds.): Special Interest Tourism. Wiley: Brisbane.

Duran, E., \& Hamarat, B. (2014). Festival attendees' motivations: the case of International Troia Festival. International Journal of Event and Festival Management, 5(2), 146-163.

Everett, S. and Aitchison, C. (2008), "The role of food tourism in sustaining regional identity: a case study of Cornwall, South West England", Journal of Sustainable Tourism, Vol. 16 No. 2, pp. 150167.

Hall, C.M., \& Sharples, L. (2003). The consumption of experience or the experience of consumption? An introduction to the tourism of taste. In C.M. Hall, L. Sharples, R. Mitchell, B. Cambourne, \& N. Macionis (Eds.), Food tourism around the world: Development, Management and Markets (pp. 1-24). Oxford: ButterworthHeinemann.

Jackson, J., Houghton, M., Russell, R., \& Triandos, P. (2005). Innovations in Measuring Economic Impacts of Regional Festivals: A Do-ItYourself Kit. Journal of Travel Research,43(4), 360-367.

Jago, L. and Dwyer, L. (2006), Economic Evaluation of Special Events. A Practitioner's Guide, Common Ground, Altona, Vic.

Jarman, D. (2018). Festival community networks and transformative place-making. Journal of Place Management and Developmet, 11(3), 335-349.

Keeley, B. (2007). Human capital: How what you know shapes your life. Paris: OECD.

Kim, Y. H., Duncan, J. L., \& Jai, T. M. (2014). A case study of a southern food festival: using a cluster analysis approach. Anatolia, 25(3), 457473.

Lee, I., Arcodia, C. (2011). The role of regional food festivals for destination branding. International Journal of Tourism Research, 13, 355-367.

Lee, S. Y., Petrick, J. F., \& Crompton, J. (2007). The roles of quality and intermediary constructs in determining festival attendees' behavioral intention. Journal of Travel Research, 45(4), 402412.
Li, J., Deng, J., \& Pierskalla, C. (2018). Impact of attendees' motivation and past experience on their attitudes toward the National Cherry Blossom Festival in Washington, DC. Urban Forestry \& Urban Greening, 36, 57-67.

McAndrews, K. (2004). Incorporating the Local Tourist at the Big Island Poke Festival in Food Tourism Around the World, Development, Management and Markets (Ed. Hall, M., Sharples, L., Mitchell, R., Macionis, N., and Cambourne, Brock). Elsevier Butterworth-Heinemann.

McDonnell, I., Allen, J., O'Toole, W. (1999). Festival and Special Event Management. Wiley.

Mossberg, L. (ed.) (2000) Evaluation of Events: Scandinavian Experiences, New York, Cognizant Communication Corporation.

Mykletun, R. J. (2009). Celebration of extreme playfulness: Ekstremsportveko at Voss. Scandinavian Journal of Hospitality and Tourism, 9(2/3), 146-176.

Picard, D., Robinson, M. (2006). Remaking Worlds: Festivals, Tourism and Change in Festivals, Tourism and Social Change (Ed. Picard, D., Robinson, M.), Channel View Publications, UK.

Rusher, K. (2004). The Bluff Oyster Festival and Regional Economic Development: Festivals as Culture Commodified in Food Tourism Around the World, Development, Management and Markets (Ed. Hall, M., Sharples, L., Mitchell, R., Macionis, N., and Cambourne, Brock). Elsevier ButterworthHeinemann.

Simpson, T. (1999). A Distant Feast: The Origins of New Zealand's Cuisine. Random House New Zealand.

Slocum, S. L., Curtis, K. R. (2018). Food and Agricultural Tourism: Theory and Best Practice. Routledge, NY.

Thrane, C. (2002). Music quality, satisfaction, and behavioral intentions within a jazz festival context. Event Management, 7(3), 143-150.

Viviers, P. A., Slabbert, E. (2012). Towards an instrument measuring community perceptions of the impacts of festivals. Journal of Human Ecology, 40(3): 197-212.

Wilks, L., \& Quinn, B. (2016). Linking social capital, cultural capital and heterotopia at the folk 
festival. Journal of Comparative Research in Anthropology and Sociology, 7(1), 23.

Yildiz, S.B. \& Polat, E. (2016). Yerel halkın Eskişehir'de düzenlenen festivallerin etkilerine yönelik algıları. Journal of Tourism and Gastronomy Studies 4 (2), 40-62.

Yolal, M., Gürsoy, D., Uysal, M., Kim, H.L. \& Karacaoğlu, S. (2016). Impacts of festivals and events on residents'well-being. Annals of Tourism Research, 2016 (61), 1-18.

Yuan, J. J., Cai, L. A., Morrison, A. M., \& Linton, S. (2005). An analysis of wine festival attendees' motivations: A synergy of wine, travel and special events?. Journal of Vacation Marketing, 11(1), 4158.

\section{Ethical approval}

This study is among the studies that do not require ethics committee approval due to not fall within the scope of research that requires one-to-one data collection from the participants and the data are obtained as secondary data. 